\title{
Information Crimes in the Structure of Russian Extremist and Terrorist Criminal Practice
}

\author{
Georgii L. Moskalev* \\ Siberian Federal University \\ Krasnoyarsk, Russian Federation
}

Received 03.08.2020, received in revised form 31.08.2020, accepted 07.10.2020

\begin{abstract}
The presented article is intended to determine the share of information crimes in the ustructure of Russian extremist and terrorist criminal practice and, as a consequence, to propose efficient methods of countering information crimes specifically for combating these crimes in general. The solution to this problem is implemented by applying statistical analysis of official data on criminality metrics supported by legal hermeneutics and sociological methods, combined with a historical approach to the subject. It is discovered that modifications in the legal regulation of information crimes in the Criminal Code have largely led to changes in the number of registered extremist and terrorist crimes in general. The article reveals a significant share of information crimes in the structure of extremist activity. Even after a decrease in 2019, it still accounts for about a third of all extremist crimes. In the structure of terrorist activity about every 10th terrorist crime is an information crime. In the extremist criminal activity and approximately in a half of all terrorist crime cases, illegal information is generally disseminated through the Internet. In approximately $75 \%$ of cases, the extremist or terrorism-related information is disseminated in the Internet by people aged under 30 years old. The vast majority of all convicts are unemployed people without higher education. The system for preventing dissemination of extremist and terrorist information should be retargeted to improve the legal culture, including the value of each social group, as well as the Internet communication culture.
\end{abstract}

Keywords: extremism, extremist crimes, extremism-related information, illegal dissemination of information, crime registration, statistics, national security strategy, terrorism, terrorist crimes, terrorist activity.

Research area: criminal law, criminology, penal law.

Citation: Moskalev, G.L. (2020). Information crimes in the structure of Russian extremist and terrorist criminal practice. J. Sib. Fed. Univ. Humanit. Soc. Sci., 13(10), 1590-1599. DOI: 10.17516/1997-13700665 .

\footnotetext{
(C) Siberian Federal University. All rights reserved

* Corresponding author E-mail address: eucaliptus@yandex.ru ORCID: 0000-0002-0418-0227
} 


\section{Introduction}

More than 10 years ago, the Decree of the President of Russian Federation No. 537 approved the National Security Strategy until 2020 (hereinafter referred to as the Strategy). Despite the urgency of the document at the time, it set some long-term tasks. The Strategy officially established a system of priorities, goals and measures in the field of domestic and foreign policy that determine the state of national security and the level of sustainable development of the state. To support the national security, the strategic national priorities were also established. The main objectives of the state and public security policy include strengthening the role of the state as a guarantor of personal security, improving the legal regulation of preventing and combating terrorism and extremism (Paragraph 38 of the Strategy). This policy should be implemented, inter alia, by improving law enforcement measures to detect, prevent, suppress and disclose the acts of terrorism and extremism (Paragraph 36 of the Strategy).

In accordance with its full title, the strategy expires this year. The results of the implementation of the Strategy can be judged, in particular, by the official statistics of the committed terrorist and extremist crimes (Legal Statistics of the General Prosecutor's Office of the Russian Federation, 2020). In the year when the document was adopted, 654 terrorist crimes and 548 extremist crimes were registered in Russia. The number of people involved in the crimes accounts for 521 and 428, respectively. For comparison, in the year 20191806 terrorist and 585 extremist crimes were registered in Russia, committed by 718 and 445 identified people, respectively. Thus, for both groups of crimes, the total increase in the number of registered crimes was 1189, and the number of identified people increased by 219 . The problem of countering extremist and terrorist crimes in the Krasnoyarsk Territory is particularly acute. By the end of 2019, in terms of the number of registered extremist crimes, the region was ranked fifth in Russia (to compare, in 2010 it was $38^{\text {th }}$ ). In general, over the past five years, the number of convicts for terrorist crimes in Russia has increased more than ninefold (Statistics: There Are 9 Times More Terrorists, 2018).

At first glance, these statistics may give rise to the idea of the insufficiency of the Strategy. However, there may be another explanation for the presented data. The number of registered crimes is directly related to the scope of acts prohibited by the Special Part of the Criminal Code of Russian Federation. The broader the prohibition, the more violations would be committed, including those that potentially could be officially registered.

In addition, Strategy evaluation results depend on the qualitative characteristics of extremist and terrorist criminal activity. The overall danger of the crimes encompassed by the statistics is not equal. Extremism and terrorism are usually associated with violence, bombs and other actions that directly threaten large groups of people. However, this domain covers a share of crimes related to the dissemination of illegal information. It is necessary to determine the share of each to propose efficient methods of countering information crimes specifically for combating terrorism and extremist crimes in general.

\section{Theoretical framework}

The way of solving this issue presented in this article is based on the results of a previous research, though it was dedicated to various aspects of the object in question.

The issue of transmitting information for terrorist purposes via the Internet is studied from several positions. Firstly, active terrorist organizations use social media to transmit secret information within their networks (Li, 2015). Investigative Data Mining (IDM) toolkit and Social Network Analysis (SNA) are used to destabilize the terrorist networks and identify the people involved in dissemination of information (Hamed, 2015). However, from the point of view of criminal law regulation, the implemented techniques only change the form of communication, not the legal judgment of criminal activities.

Secondly, the "Internet is used by international insurgents, jihadists, and terrorist organizations as a tool for radicalization and recruitment" (Theohary, Rollins, 2011). In- 
deed, according to the research results, terrorist organizations are finding new recruitment methods (Hofmann, 2015). As a result of analysing the process of attracting new participants by the major terrorist organizations, the researchers conclude that the highest efficiency is demonstrated by long-term and even cyclical recruitment (Bloom, 2016). Most studies point to an ideological, mainly religious, influence (Klein, 2016) on a person during recruitment (Scorgie-Porter, 2015), and the authors call the Internet the main means of involvement (Mashechkin et al., 2016). Although the described activity consists in transmitting information, it is not the nature of the information that makes it socially dangerous. Therefore, in this study such crimes cannot be classified as information-related either.

Finally, Russian Criminal Code encompasses the actus rea crimes that include dissemination of specific extremist and terrorist information. Their public danger consists not only in the fact of dissemination of information, but also in the specifics of its content, which is illegal in nature. Such crimes are usually referred to as information crimes (Beliakov, 2021). Despite the existence of research on information crimes in general (Beliakov, 2021) and the way they are perceived by the society (Prieto Curiel et al., 2020), the issue of their place in the structure of extremist and terrorist criminal activity has not been studied yet.

It is known that "information crime passes through several stages from initiation to execution and commitment of the crime. The crime, however, may or may not end as desired by the actor as it may be suspended at the stage of initiation and fail to achieve its goal" (Krit, 2019). That is one of the possible reasons why corpus delicti of information-related extremist and terrorist crimes in Russian law does not include results of a crime as a necessary element. In other words, it is enough to commit a prohibited action itself to be liable for the crime. This is another evidence that our approach to understanding information crimes is correct: as far as their threat is the specificity of the disseminated information, there is no need to wait until the criminal goal is achieved to enforce a punishment on the offender.
It is worth mentioning that the official lists of extremist and terrorist crimes are slightly different: one is provided by the Prosecutor General's Office of the Russian Federation and the Ministry of internal Affairs of Russia, and another - by the Supreme Court of Russia. Fortunately, the crimes covered by the subject of this study are present in both lists. Among the acts prohibited by criminal law, the extremist and terrorist information crimes include:

- Public calls for terrorist activities, public justification of terrorism or propaganda of terrorism (art. 205.2 of the Criminal code of Russian Federation);

- Not reporting a terrorist crime (art. 205.6);

- Public calls for extremist activities (art. 280);

- Public calls for actions aimed at violating the territorial integrity of the Russian Federation (art. 280.1);

- Inciting hatred or enmity, as well as humiliation of human dignity on the grounds of gender, race, nationality, language, origin, attitude to religion, as well as belonging to a social group (art. 282).

\section{Methods}

To fulfil the objective of this article, several investigation methods of investigation were employed. To determine the share of information crimes in the structure of extremist and terrorist criminal activity, it is necessary, first of all, to do a statistical analysis of the official data on registered crimes. In this article, we examine the data for the years 20102019. This is the period of implementation of the National Security Strategy of Russia mentioned above.

Importantly, during this period, the number of information crimes in the Criminal Code of Russia varied. Many of the mentioned crimes were included in the period from 2010 to 2019. The number of the acts prohibited by the specified articles of the criminal law has also changed. Of course, these legal amendments affected the statistics. Thus, the statistical method of research should be supported by special legal methods of hermeneutics, combined with a historical approach to the study. 
Expert interviews, surveys, and content analysis of information concerning the activities of non-governmental patriotic organizations are used as auxiliary research methods. They demonstrate the correlation between the statistical data, criminal law regulations and actual behaviour of individuals and organizations. The results of the study appear to be clearly demonstrated.

\section{Discussion}

The study of the issue should start with the official statistics of the registered terrorist and extremist crimes, kept by the Prosecutor General's Office of the Russian Federation. Data for the period under review are shown in Table 1.

The data shows that the number of registered terrorist crimes has been growing since 2010 and peaked in 2016. In the years 20172018, their number decreased, but in 2019, it returned to the value of 2017 . Thus, it can be stated that in the period 2017-2019, the dynamics of changes in registered terrorist crimes has stabilized.

The changes in the number of the registered extremist crimes look different. In the period of 2010-2017, their number has been consistently growing. The decrease in the number of registered extremist crimes in 2018 was insignificant. At the same time, the 2019 figure seems striking. The level of registered extremist crimes in the past year compared to 2018 dropped by more than two times to be the lowest value for the entire period under review.

These changes in the official statistics of registered crimes can be explained by the modernization of criminal legislation in 2010-2019. The broader the scope of the criminal law, the more crimes are registered. Thus, the reason for the increase in the number of crimes committed may be the process of criminalization, and the decrease in their number, on the contrary, refers to decriminalization.

Over the past few years, the Criminal Code of the Russian Federation has included many articles envisaging liability for actions accompanying extremist and terrorist activities. These new crimes have complemented the content of the extremist and terrorist crimes.

The boundaries of the criminal law prohibition established by the articles of the Criminal Code of the Russian Federation that provide for liability for committing extremist crimes did not change significantly in 2010-2017. However, new extremist crimes appeared. In 2013, Article 280.1, providing for liability for public calls for actions aimed at violating the territorial integrity of the Russian Federation, was introduced into the Code. In 2014, the Code incorporated Article 282.3 on liability for financing extremist activities. At the end of 2018, the disposition of Article 282 was modified. As a result, the least dangerous forms of incitement to hatred or enmity, as well as humiliation of human dignity, were decriminalized and transferred to the scope of administrative offences. As a consequence, the statistics of registered crimes in 2019 did not include the first committed actions aimed at inciting hatred or enmity, in 2018 and before, they were regarded as extremist crimes. At the same time, as it has been mentioned above, in 2019 only 585 extremist crimes were registered, which is 700 less than in the previous year. It is appropriate to assume that 6 out of 10 extremist crimes in 2018 were decriminalized acts, previously covered by Article 282 of the Criminal code of the Russian Federation.

Changes in the terrorist crimes look different compared to the extremist ones. The analysis of articles on liability for terrorist crimes discovers that in this branch of criminal law, no

Table 1

\begin{tabular}{|l|c|c|c|c|c|c|c|c|c|c|}
\hline & 2010 & 2011 & 2012 & 2013 & 2014 & 2015 & 2016 & 2017 & 2018 & 2019 \\
\hline $\begin{array}{l}\text { Number of registered } \\
\text { terrorist crimes }\end{array}$ & 581 & 622 & 637 & 661 & 1128 & 1539 & 2227 & 1871 & 1679 & 1806 \\
\hline $\begin{array}{l}\text { Number of registered } \\
\text { extremist crimes }\end{array}$ & 656 & 622 & 696 & 896 & 1034 & 1329 & 1450 & 1521 & 1265 & 585 \\
\hline
\end{tabular}


decriminalization was carried out. The amendments introduced to most of the articles were intended to change the limits of possible punishment or clarify the wording, but not to establish criminal liability for the acts that had not been previously considered to be a crime. At the same time, there are acts that still fall within the scope of the criminal prohibition, mainly due to the introduction of new articles in the Criminal Code of the Russian Federation. In 2013, Article 205.3 criminalized training for terrorist activities; Article 205.4 criminalized organization of terrorist community and participation in such; Article 205.5 covered organization of terrorist organization activities and participation in such; Part 2 of Article 208 provided for liability for participation in an armed formation on the territory of a foreign state not provided for by the legislation of that state for any purposes contrary to the interests of the Russian Federation. These changes made an impact on statistics: the number of registered terrorist crimes in 2014 was almost 2 times higher than in 2013. In 2016, Article 205.6 proclaimed liability for not reporting a terrorist crime; this is the only considered information crime that envisages liability not for the dissemination of illegal information, but for malicious non-reporting of relevant information. In 2017, Article 205.2 was supplemented with a provision on propaganda of terrorism, which is one of the ways of illegal dissemination of terrorism-related information foreseen by the Code.

Thus, there is a correlation between the number of acts prohibited by the Criminal Code of the Russian Federation and changes in the statistics of registered extremist and terrorist crimes. It should be noted that among all the changes in the criminal law concerning liability for terrorist and extremist crimes, the intro- duction of Articles 280.1, 205.2, 205.6 in the Code, as well as the change in the boundaries of the criminal law prohibition in Article 282, relate to information crimes. It is easy to see that most of the changes to the Code mentioned are modifications of the said articles. Therefore, the value of information crimes in the structure of extremist and terrorist criminality in Russia is more than significant: modifications in the legal regulation of these crimes in the Russian Criminal Code have caused a dramatic change in the number of registered extremist and terrorist crimes.

At the same time, this preliminary conclusion does not allow us to estimate the share of the information crimes in the system of extremist and terrorist criminal activity. Unfortunately, the official statistics of registered crimes are not broken by articles of the Russian Criminal code. However, this information can be obtained from the statistics on the number of convicted people maintained by the Judicial Department of the Supreme Court of the Russian Federation. Since the current state of crime rate is of the greatest interest, we will examine the values for the period of 2017-2019. The number of people convicted of information extremist crimes is presented in Table 2.

From the data presented in the table, it may be concluded that the number of convicts under Article 280 slightly decreases every year, and public calls for actions aimed at violating the territorial integrity of the Russian Federation (Article 280.1) hardly makes any difference in the total number of convicts for information extremist crimes. The most statistically significant phenomenon was the fall in the number of convicts under Article 282 in 2019. We have previously mentioned that at the end of 2018, the disposition of Article 282 was modified by

Table 2

\begin{tabular}{|l|c|c|c|}
\hline & 2017 & 2018 & 2019 \\
\hline Art. 280 & 170 & 159 & 145 \\
\hline Art. 280.1 & 8 & 10 & 4 \\
\hline Art. 282 & 571 & 518 & 36 \\
\hline Total & 749 & 648 & 185 \\
\hline
\end{tabular}


decriminalization of the $1^{\text {st }}$ time committed incitement to hatred or enmity, as well as humiliation of human dignity. We have just seen how this legislative manoeuvre affected the registered extremist crimes statistics. Along with the presented data, this fact proves a direct correlation between the number of registered crimes and that of convicted people. This correlation is described in the following numbers:

- in 2017, for 1521 registered extremist crimes, there were 749 people convicted of information extremist crimes (49.2\%);

- in 2018, for 1265 registered extremist crimes, there are 648 people convicted of information extremist crimes (51.2\%);

- in 2019, for 585 registered extremist crimes, there are 185 people convicted of information extremist crimes (31.6\%).

Therefore, information crimes constitute a significant share in the structure of extremist criminal activity. In 2019, it decreased due to legislative changes to Article 282, but still accounts for about a third of all extremist crimes.

Next, we will analyse the number of people convicted of information terrorist crimes, in accordance with the data presented in Table 3.

The presented data discloses the trend of a slight increase in the number of people convicted of information terrorist crimes. The correlation between the numbers of registered terrorist crimes and those of people convicted of information terrorist crimes is the following:

- in 2017, for 1871 registered terrorist crimes, there were 115 people convicted of information terrorist crimes $(6.1 \%)$;

- in 2018, for 1679 registered terrorist crimes, there were 175 people convicted of information terrorist crimes (10.4\%);

- in 2019, for 1806 registered terrorist crimes, there were 180 people convicted of information terrorist crimes $(9.9 \%)$.
Thus, in the structure of terrorist criminal activity, information crimes are not as significant, but still about every $10^{\text {th }}$ terrorist crime is information-related.

Based on the objective statistic data, our hypothesis that information crimes constitute a significant part in the structure of extremist and terrorist criminality brought together is confirmed by the interviewed advocates practicing in this field. In the field, there are just a few of them. According to their personal observations, in the Krasnoyarsk Territory, a large part of committed extremist and terrorist crimes are associated with illegal dissemination of information. This explains why the Krasnoyarsk Territory which, fortunately, has never suffered a terrorist attack, consistently ranks high in terms of the number of registered extremist and terrorist crimes. In accordance with Federal State Statistics Service data, the vast majority of the local residents have access to the Internet, which allows them to exchange any information, including illegal.

Unfortunately, the statistics do not contain any objective data on how many information crimes were committed by disseminating illegal information in the Internet. However, a reasonable assumption can sometimes be made from the legal qualification of the act. For example, according to the official data, out of 170 people convicted under Article 280 in 2017, 140 were found guilty under Part 2 of this Article, which envisages liability for public calls to extremist activities distributed in the media or on the Internet. Under Part 2, 140 people out of 159 were convicted in 2018 and 132 out of 145 were convicted in 2019. Article 205.2 has a structure similar to Article 280 of the Code: in Part 2, it foresees liability for public calls for terrorist activities, public justification of terrorism or propaganda of terrorism committed

Table 3

\begin{tabular}{|c|c|c|c|}
\hline & 2017 & 2018 & 2019 \\
\hline Art. 205.2 & 96 & 120 & 126 \\
\hline Art. 285.6 & 19 & 55 & 54 \\
\hline Total & 115 & 175 & 180 \\
\hline
\end{tabular}


by disseminating this information in the media or on the Internet. According to the official data, under Part 2 of Article 205.2, in 2018, 52 people were convicted under the article out of 120, and in 2019, 69 out of 126. Therefore, the objective data confirm that the dissemination of illegal information during commission of information crimes is carried out through the Internet, while this mostly relates to extremist crimes.

According to the data obtained from interviewing the Antiterrorist Commission of the Krasnoyarsk Territory, $70 \%$ of information crimes are committed by people aged under 30. This data is surprisingly confirmed by the statistics of activity in vk.com, the most popular social network in Russia. The most active authors of unique content in this social network, constituting approximately $70 \%$ of the content writers, have not reached the age of 30. At the same time, researchers note that in $90 \%$ of convictions of information-related extremist crimes, the information was transmitted remotely through VK.com social network. (Ivantsov et al., 2018). Consequently, there is a direct correlation between the share of extremist crimes committed by people under 30 and the share of authors of unique content in the social network that have not reached the age of 30. This means that the determinants of extremist criminal activity depend no on the age of the criminals, but their activity in Internet.

According to the report on demographic characteristics of convicts for 2019, the Judicial Department of the Supreme Court of the Russian Federation, $75.8 \%$ of people convicted of public calls for extremist activities in the media or on the Internet are people under the age of 30. The share of people convicted of public calls for terrorist activities, public justification of terrorism or propaganda of terrorism committed by disseminating this information in the media or on the Internet aged under 30 constitutes $72.8 \%$. According to statistics, the vast majority of all convicts are unemployed people without higher education.

So, the reasons for the disappointing statistics of extremist activity are easier to find within the youth community, since the share of youth in the statistics is simply higher.
Firstly, people simply do not know how to distinguish between extremist and non-extremist information. A survey of 100 people aged 17-21 years old conducted by the authors in spring 2018 demonstrated that only one person out of 50 can name at least several distinctive features of extremism or extremist information. This situation is explained with several reasons.

- There is no definition of extremism in the legislation, and the distinctive features of extremist information can be found only by interpreting the provisions of the criminal law and its enforcement practice. Of course, none of the ordinary citizens do this. In addition, the extremist nature of information can often be discovered only by an expert linguist. Judges constantly turn to such experts, investigating extremist and terrorist crimes.

- Officers of Centre "E" of the Main Department of the Ministry of internal Affairs of Russia for the Krasnoyarsk Territory engaged in countering extremism, in the course of their activities in 2018, offered young citizens checking any information they were going to publish online using a corpus of extremist materials banned by the courts of Russia (Federal List of Extremist Materials). However, this recommendation does not make sense. At the present moment, the corpus contains over 5000 titles of prohibited information. But even if we learn them by heart, there will be no guarantees that extremist information would not be disseminated. The criminal law prohibits the dissemination of any information of such nature, not only the specific items previously banned by the courts.

Secondly, people do not care much about the information that can be found online. During our survey, a simple example of a text containing an insult of a small social group was presented for examination. Interestingly, the respondents found it suitable for publishing online, but considered it consider it inappropriate for broadcasting on television.

\section{Conclusion}

It is customary to believe that an efficient way of preventing such crimes is the improvement of the monitoring of the existing and 
emerging Internet resources, including timely blocking and removal of extremist components (Ivantsov et al., 2018). There is no need to deny the necessity of such surveillance measures. However, in our opinion, it is not enough to combat extremist and terrorist information crimes. As we can see in the article, their determinants are different.

The measures to be taken to prevent the illegal dissemination of extremism and terrorism-related information are pretty obvious. There should be a system of classes to improve legal culture, including the value of each national, ethnic, religious, ideological or other social group, as well as online communication culture.

At the moment, there are so-called patriotic organizations try running activities to combat the extremist crimes.

In practice, this means teaching young people the skills they may need for military service: practical shooting skills, drill training, ability to serve arms, chemical protection skills, mountain training and so on. Such activities are, indeed, an important and necessary component of pre-conscription training. However, in the absence of a proper ideological base, the efforts of these organizations can benefit the opposite side. The same knowledge and skills can strengthen illegal armed groups, extremist and terrorist organizations.

In other words, this is not the speed of assembly and disassembly of the gun, the ac- curacy of shooting, camouflage outfit or the availability of drill training that distinguishes a patriot from a terrorist (they may have all these features in common). It is the purpose of their activity that makes them different. Unfortunately, the local patriotic organizations have not accepted this postulate yet. In particular, the official website of a large military and patriotic organization of Krasnoyarsk presents the review of the events organized for their members, including a relay race, a paintball competition, a small-calibre rifle shooting competition, multiple wrestling competitions, film sessions, climbing competitions, territory cleaning events, mountain-assault training competitions. There is no need to explain that these activities aimed at the physical development do not include any value orientation or improvement of digital communication culture.

Therefore, to prevent the dissemination of extremist and terrorist information, the approach to the system needs to be reviewed. Considering the share of information crimes in the structure of extremist and terrorist activity, the efficiency of this system can significantly reduce the number of committed crimes and people involved in the criminal world. Otherwise, the changes in the numbers of registered crimes will still depend mainly on the changes in the Russian Criminal code, and not on changes in the actual behaviour of the society.

\section{References}

Beliakov, A.V. (2021). Knowledge and Information as an Object of Criminal Law Protection. In Lecture Notes in Networks and Systems, 133, 3-9.

Bloom, M. (2016). Constructing Expertise: Terrorist Recruitment and "Talent Spotting" in the PIRA, Al Qaeda, and ISIS. In Studies in Conflict and Terrorism, 1, 1-21.

Decree of the President of Russian Federation No. 537 "National Security Strategy of Russian Federation until 2020". Available at: http://www.kremlin.ru/supplement/424 (accessed 01 May 2020).

Hamed, I., Charrad, M. (2015). Recognizing Information Spreaders in Terrorist Networks: 26/11 attack case study. In Lecture Notes in Business Information Processing, 233, 27-382.

Hofmann, D.C. (2015). Quantifying and Qualifying Charisma: A Theoretical Framework for Measuring the Presence of Charismatic Authority in Terrorist Groups. In Studies in Conflict and Terrorism, 38 (9), $710-733$.

Instruction of the Prosecutor General's Office of Russia No. 487/11 and the Ministry of Internal Affairs of Russia No. 1 "About Introduction of Lists of Articles of the Criminal Code of the Russian Federa- 
tion Used in Forming Statistical Reports" (2019). Available at: https://www.garant.ru/products/ipo/prime/ doc/71231728/ (accessed 01 May 2020).

Ivantsov, S.V., Borisov, S.V., Usembaeva, G.I., Muzychuk, T.L., Tishchenko, I.I. (2018). Relevant Problems of Improving the Measures of Criminological Prevention of Extremist Crimes Committed Using Information and Telecommunication Networks. In Russian Journal of Criminology, 12 (6), 776-784.

Klein, G.R. (2016). Ideology Isn't Everything: Transnational Terrorism, Recruitment Incentives, and Attack Casualties. In Terrorism and Political Violence, 28 (5), 868-887.

Krit, H.H.A. (2019). Learning about the Characteristics of the Initiation of Information Crime. In International Journal of Innovation, Creativity and Change, 7 (8), 404-416.

Legal Statistics of the Prosecutor General's Office of the Russian Federation (2020). Available at: http://crimestat.ru (accessed 01 May 2020).

Li, Z. Sun, D. Evaluation on the Effectiveness of Information Transmission in Terrorist Networks. In $8^{\text {th }}$ International Symposium on Computational Intelligence and Design, 2, 457-460.

Mashechkin, I., Petrovskiy, M., Pospelova, I., Tsarev, D. (2016). Automatic Summarization and Keyword Extraction Methods for Discovering Extremist Information on the Internet. In CEUR Workshop Proceedings, 1763, 188-198.

Prieto Curiel, R., Cresci, S., Muntean, C.I., Bishop, S.R. (2020). Crime and Its Fear in Social Media. In Palgrave Communications, 6,1 .

Report of the Judicial Department of the Supreme Court of the Russian Federation on the Number of Convicted People of All Types of Crimes of the Criminal Code of the Russian Federation for 2017 (2017). Available at: http://www.cdep.ru/index.php?id=79\&item=4572 (accessed 01 May 2020).

Report of the Judicial Department of the Supreme Court of the Russian Federation on the Number of Convicted People of All Types of Crimes of the Criminal Code of the Russian Federation for 2018 (2018). Available at: http://www.cdep.ru/index.php?id=79\&item=4894 (accessed 01 May 2020).

Report of the Judicial Department of the Supreme Court of the Russian Federation on the Number of Convicted People for All Types of Crimes of the Criminal Code of the Russian Federation for 2019 (2019). Available at: http://www.cdep.ru/index.php?id=79\&item=5259 (accessed 01 May 2020).

Report of the Judicial Department of the Supreme Court of the Russian Federation on Demographic Characteristics of Convicted People of All Types of Crimes of the Criminal Code of the Russian Federation for 2019 (2019). Available at: http://www.cdep.ru/index.php?id=79\&item=5259 (accessed 01 May 2020).

Resolution of the Plenum of the Supreme Court of the Russian Federation "On Some Issues of Judicial Practice in Criminal Cases of Terrorist Crimes" No. 1 (2016). Available at: http://www.consultant.ru/document/cons_doc_LAW_125957/(accessed 01 May 2020).

Scorgie-Porter, L. (2015). Militant Islamists or Borderland Dissidents? An Exploration into the Allied Democratic Forces' Recruitment Practices and Constitution. In Journal of Modern African Studies, 53 (1), $1-25$.

Statistics: There Are 9 Times More Terrorists (2018). Available at: http://scienceport.ru/news/statistika-terroristov-stalo-v-9-raz-bolshe/ (accessed 01 May 2020).

Statistics for Vkontakte (2017). Available at: https://vk.com/live (accessed 01 May 2020).

Theohary, C.A., Rollins, J. (2011). Terrorist Use of the Internet: Information Operations in Cyberspace. In Countering Terrorism: U.S. Efforts and Country Cooperation, 29-45.

Federal List of Extremist Materials of the Ministry of Justice of the Russian Federation (2019). Available at: http://minjust.gov.ru/ru/extremist-materials (accessed 01 May 2020).

Federal Statistical Observation Form No. 1-it "Questionnaire for a Sample Survey of the Population on the Use of Information Technologies and Information and Telecommunication Networks" of Department of Statistics of Education, Science and Innovation of the Federal State Statistics Service in 2019 (2019). Available at: http://www.gks.ru/free_doc/new_site/business/it/fed_nabl-croc/index.html (accessed 01 May 2020). 


\title{
Информационные преступления экстремистской и террористической направленности в структуре российской преступности
}

\section{Г.Л. Москалев}

Сибирский федеральный университет

Российская Федераиия, Красноярск

\begin{abstract}
Аннотация. Целью статьи является определение доли информационных преступлений в структуре экстремистской и террористической преступности в России. Ее (цели) достижение осуществляется путем применения статистического анализа официальных данных о показателях преступности, подкрепленного методами юридической герменевтики, социологическими методами в сочетании с историческим подходом к предмету исследования. Установлено, что изменения в правовой регламентации информационных преступлений в Уголовном кодексе РФ в значительной степени привели к изменению количества зарегистрированных экстремистских и террористических преступлений в целом. В работе продемонстрировано, что в структуре экстремистской преступности доля информационных преступлений значительна. В 2019 г. она снизилась, но по-прежнему составляет около трети всех преступлений экстремистской направленности. В структуре террористической преступности примерно каждое 10-е преступление является информационным. Распространение информации осуществляется главным образом через интернет при совершении преступлений экстремистской направленности и половине случаев совершения информационных преступлений террористической направленности. Примерно в $75 \%$ случаев распространение экстремистской или террористической информации в интернете осуществляется лицами, не достигшими 30-летнего возраста. Подавляющее большинство всех осужденных - безработные, не имеющие высшего образования. Система предупреждения распространения экстремистской и террористической информации должна быть переориентирована на повышение правовой культуры, в том числе ценности каждой социальной группы, а также на повышение культуры общения в интернете.
\end{abstract}

Ключевые слова: экстремизм, преступления экстремистской направленности, информация экстремистского содержания, незаконное распространение информации, регистрация преступлений, статистика, терроризм, преступления террористической направленности, террористическая деятельность.

Научная специальность: 12.00 .08 - уголовное право, криминология, уголовноисполнительное право. 